\title{
Exchanging carrion for fresh meat: the vulture Cathartes burrovianus (Aves, Cathartidae) preys on the snake Xenodon merremii (Serpentes, Dipsadidae) in southeastern Brazil
}

\author{
Thiago Oliveira e Almeida ${ }^{1 *}$ \\ Fernanda Carvalho Machado ${ }^{1}$ \\ Henrique Caldeira Costa ${ }^{2}$ \\ ${ }^{1}$ Pontifícia Universidade Católica de Minas Gerais, Laboratório de Ornitologia \\ Museu de Ciências Naturais PUC Minas \\ Avenida Dom José Gaspar, 290, CEP 30535-901, Belo Horizonte-MG, Brasil \\ ${ }^{2}$ Universidade Federal de Viçosa, Departamento de Biologia Animal \\ Museu de Zoologia João Moojen, Vila Gianetti 32, CEP 36570-000, Viçosa-MG, Brasil \\ * Corresponding author \\ thiagoalmeida_bio@yahoo.com.br
}

Submetido em 06/02/2010

Aceito para publicação em 07/08/2010

\section{Resumo}

Trocando carniça por carne fresca: o urubu Cathartes burrovianus (Aves, Cathartidae) caça a serpente Xenodon merremii (Serpentes, Dipsadidae) no sudeste do Brasil. O urubu-de-cabeça-amarela (Cathartes burrovianus) é conhecido pelo hábito necrofágico, típico dos Cathartidae. Contudo, membros desta família também caçam presas vivas, embora este comportamento seja pouco documentado. Nós reportamos aqui um C. burrovianus predando a serpente não-peçonhenta, Xenodon merremii, em uma área antropizada no sudeste do Brasil.

Unitermos: boipeva, dieta, Minas Gerais, predação, urubu-de-cabeça-amarela

\section{Abstract}

The Lesser Yellow-headed Vulture (Cathartes burrovianus) is known mainly for its necrophagic habits, typical of the Cathartidae. However, members of this family also hunt live prey, though this behavior is not well documented. We report here on a C. burrovianus preying on the non-venomous snake Xenodon merremii, at an anthropogenic site in southeastern Brazil.

Key words: boipeva, diet, Lesser Yellow-headed Vulture, Minas Gerais, predation 
The New World vultures (Cathartidae) are known for their importance as consumers of animal carcasses (Sick, 2001). According to some authors, vultures feed solely on carrion (e.g. Mota Júnior, 1990; Telino-Júnior et al., 2005). However, the consumption of fruits, live invertebrates and vertebrates by some species is recorded (Brown and Amadon, 1989; Sick, 2001).

The Lesser Yellow-headed Vulture, Cathartes burrovianus Cassin, 1845 occurs throughout most of South America, with exception of Chile (Brown and Amadon, 1989; Ferguson-Lees and Christie, 2005). It inhabits small forest patches, riparian forests, swamp areas and even open formations, including the vicinity of cultivated fields and the borders of highways (where it waits for road-killed animals) (Brown and Amadon 1989; Sick, 2001; Ferguson-Lees and Christie, 2005).

Cathartes burrovianus feeds mostly on carrion of smaller animals and is rarely recorded eating a large carcass in company of others vultures (Sigrist, 2006). This vulture also feeds on insects (adults and larvae), amphibians, fish and snakes (Sigrist, 2006) and even birds (see Silveira and Belmonte, 2005 for a possible attempt of predation of the nests of the parakeet Guarouba guarouba). For snake prey, however, no information on the prey species is available. This note contributes to the knowledge of the hunting activity of $C$. burrovianus based on an episode recorded in southeastern Brazil.

On 07 June 2009, a C. burrovianus was seen repeatedly flying low over an open area in the vicinity of a dirt road near an abandoned pen $\left(18^{\circ} 35^{\prime} 18.25^{\prime}\right.$ 'S, $41^{\circ} 51^{\prime} 12.46^{\prime \prime} \mathrm{W}$; about $190 \mathrm{~m}$ above sea level) in the municipality of Frei Inocêncio, state of Minas Gerais, southeastern Brazil.

It landed close to a clump of grass, and attacked its intended prey, which could not be identified at the time. The vulture then pulled something with its bill but kept its head lowered for a few minutes. When the bird raised its head again, its bill held what appeared to be flesh (Figure 1).

The vulture flew off, leaving its prey, as the observer moved within about five meters of it. Shortly after, the bird was seen flying repeatedly and low at another area in the vicinity of our observation. The half-eaten snake (Figure 2) was still twitching when we found it. The snake remains were not collected but were photographed as a voucher.

The prey of the vulture was identified as Xenodon merremii (Wagler, 1824), popularly known as boipeva. This is a non-venomous, diurnal and terrestrial species (Marques et al., 2001) with a wide distribution in South America. It inhabits open areas including anthropogenic sites (Peters and Orejas-Miranda, 1970; Argôlo, 2004), where it feeds on toads (Vanzolini et al., 1980; Vitt and Vangilder, 1983). Xenodon merremii is also well known for its color polymorphism (Dirksen and Duarte, 1998), with some phenotypes considered as mimics of the venomous snakes of the genus Bothrops and Crotalus (Dirksen and Duarte, 1998; Brodie III and Brodie Jr., 2004), leading general people to mistakenly identify it as lanceheads (Bothrops) or rattlesnakes (Crotalus).

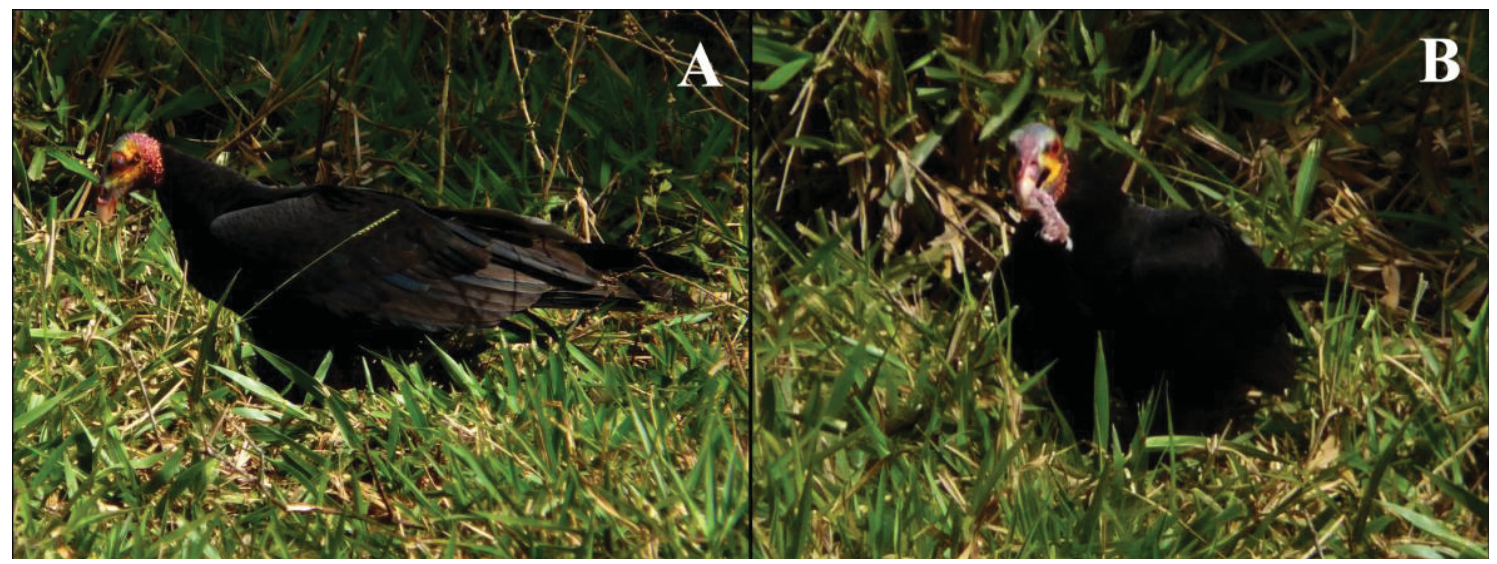

FIGURE 1: (A) Cathartes burrovianus apparently inspecting its intended prey, a Xenodon merremii, (B) The bird holding a piece torn from the snake's body. 


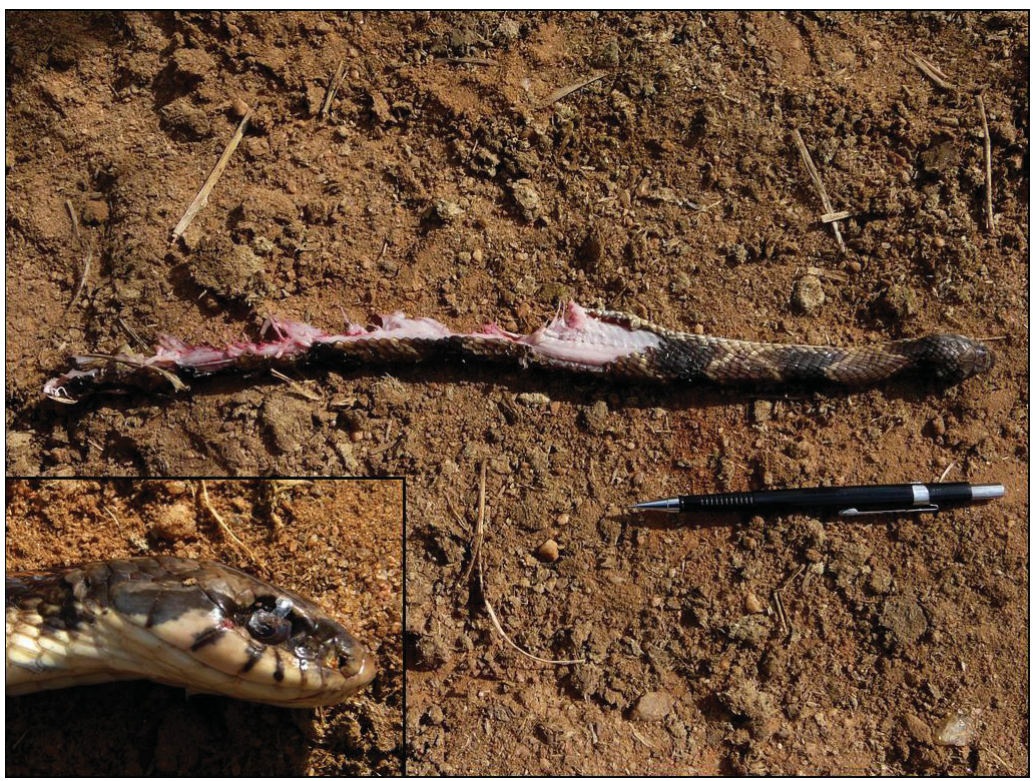

FIGURE 2: Xenodon merremii killed by Cathartes burrovianus. Note that the snake's mid-posterior region was eaten first.

It is important to note that the possible mimicry of a venomous snake (Bothrops) by the specimen reported here was not sufficient to avoid its predation. In fact, even venomous snakes are sometimes preyed by birds (e.g. Laurencio, 2005; DuVal et al., 2006).

Recently, Costa et al. (2009) reported X. merremii as prey of the laughing falcon, Herpetotheres cachinnans, in a situation similar to that described here. The diurnal activity of $X$. merremii and its occurrence in open environments, even those altered by human action, make this snake potential prey for visually oriented predators like raptors.

\section{Acknowledgements}

We thank Jussara S. Dayrell, Mário R. de Moura, Luiz G. M. P. Fernandes, Helberth J. C. Peixoto and Rodrigo M. Pessoa for valuable assistance. Táxon Meio Ambiente and Limiar Engenharia Ambiental gave financial support to TOA and FCM during field work. Alan Resetar and Kathleen M. Kelly kindly conducted an English review and three anonymous referees gave useful suggestions to improve the text.

\section{References}

Argôlo, A. J. S. 2004. As Serpentes dos cacauais do sudeste da Bahia. Editora da UESC, Ilhéus, Brazil, 260pp.

Brodie III, E. D.; Brodie Jr., E. D. 2004. Venomous snake mimicry. In: Campbell, J. A. \& Lamar, W. W. (Eds). Venomous reptiles of the western hemisphere (Vol. II). Cornell University Press, Ithaca, USA, p.617-633.

Brown, L.; Amadon, D. 1989. Eagles, Hawks and Falcons of the world. The Wellfleet Press, New Jersey, USA, 945pp.

Costa, H. C.; Assis, C. L.; Werneck, H. A.; Nunes, A. V.; Feio, R. N. 2009. Ataque de um falcão acauã (Herpetotheres cachinnans) sobre a serpente boipeva (Xenodon merremii) na Mata Atlântica de Minas Gerais, sudeste do Brasil. Revista Brasileira de Zoociências, 11 (2): 171-173.

Dirksen, L.; Duarte, M. R. 1998. Polymorphismus in Waglerophis merremii (Wagler, 1824) mit 1 Abbildung von M. R. Duarte. Herpetofauna, 20 (115): 20.

DuVal, E. H.; Greene, H. W.; Manno, K. L. 2006. Laughing falcon (Herpetotheres cachinnans) Predation on coral snakes (Micrurus nigrocinctus). Biotropica, 38 (4): 566-568.

Ferguson-Lees, J.; Christie, D. A. 2005. Raptors of the world. Princeton University Press, New Jersey, USA, 320pp.

Laurencio, D. 2005. Bothriechis schlegelli (Eye-lash Palm Pitviper, Bocaracá). Attempted predation. Herpetological Review, 36 (2): 188 .

Marques, O. A. V.; Eterovic, A.; Sazima, I. 2001. Serpentes da Mata Atlântica: guia ilustrado para a Serra do Mar. Holos Editora, Ribeirão Preto, Brazil, 184pp.

Mota Júnior, J. C. 1990. Estrutura trófica e composição das avifaunas de três hábitats terrestres na região central do estado de São Paulo. Revista Brasileira de Ornitologia, 1: 65-71. 
Peters, J. A.; Orejas-Miranda, B. 1970. Catalogue of Neotropical Squamata. Part I. Snakes. Bulletin of the United States National Museum, 297: 1-347.

Sick, H. 2001. Ornitologia Brasileira. Editora Nova Fronteira, Rio de Janeiro, Brazil, 912pp.

Sigrist, T. 2006. Aves do Brasil: uma visão artística. Avis Brasilis Editora, São Paulo, Brazil, 672pp.

Silveira, L. F.; Belmonte, F. J. 2005. Comportamento reprodutivo e hábitos da ararajuba, Guarouba guarouba, no município de Tailândia, Pará. Revista Brasileira de Ornitologia, 13 (1): 89-93.

Telino-Júnior, W. R.; Dias, M. M.; Azevedo Júnior, S. M.; LyraNeves, R. M.; Larrazábal, M. E. L. 2005. Estrutura trófica da avifauna na Reserva Estadual de Gurjaú, Zona da mata Sul, Pernambuco, Brasil. Revista Brasileira de Zoologia, 22 (4): 962973.

Vanzolini, P. E.; Ramos-Costa, A. M. M.; Vitt, L. J. 1980. Répteis das Caatingas. Academia Brasileira de Ciências, Rio de Janeiro, Brazil, 161pp.

Vitt, L. J.; Vangilder, L. D. 1983. Ecology of a snake community in northeastern Brazil. Amphibia-Reptilia, 4 (2-4): 273-296. 